\title{
PERSPEKTIF INTEGRASI ILMU TERHA- DAP ISU MENENTUKAN AWAL WAKTU SOLAT SUBUH
}

\section{The Knowledge Integration Perspective on the Issue of Determining the Time for the Beginning of Fajr Prayer}

\author{
Mohammaddin Abdul Niri* \\ Raihana Abdul Wahab** \\ Mohd Saiful Anwar Mohd Nawawi ${ }^{* * *}$ \\ Abdul Razak Nayan****
}

\begin{abstract}
The knowledge integration perspective between Shariah and astronomy is structured as the framework to study the issue of determining the time for the beginning of Fajr prayer. As such, the dawn sky observation was conducted at Pantai Bak-bak, Kudat, Sabah using the SQM-LU instrument. The sun's altitude then
\end{abstract}

* Senior Lecturer, Islamic Astronomy Programme, Department of Fiqh and Usul, Academy of Islamic Studies, University of Malaya, 50603 Kuala Lumpur. mohammaddin@um.edu.my

** Senior Lecturer, Islamic Astronomy Programme, Department of Fiqh and Usul, Academy of Islamic Studies, University of Malaya, 50603 Kuala Lumpur. raihanawahab@um.edu.my

*** Senior Lecturer, Islamic Astronomy Programme, Department of Fiqh and Usul, Academy of Islamic Studies, University of Malaya, 50603 Kuala Lumpur. saifulanwar@um.edu.my

**** Research Assistant, BK065-2017 Project, Department of Fiqh and Usul, Academy of Islamic Studies, University of Malaya, 50603 Kuala Lumpur. razaknayan96@gmail.com 
was obtained and the appropriate value to indicate both the dawn of șadiq at the observation site at that time and the beginning of fajr prayer time is $-20.174^{\circ}$ $\pm 0.170^{\circ}$. As a reflection from the knowledge integration perspective, the value is not strong enough as it was obtained only from the graph analysis with no data recorded from the naked-eye observation and the DSLR camera due to the local sky conditions and cloudy horizon. The best value of observation can be considered as a result of the knowledge integration between methods in Shariah and astronomy, especially with the combination of the naked-eye observation as the foundation and then strengthen with the astronomical approach through mathematical calculation and aided-eye observation in the field.

Keywords: knowledge integration, Islamic sciences, Islamic astronomy, Islamic prayer time, SQM

\section{PENGENALAN}

Penentuan awal waktu solat Subuh mempunyai kesukaran kerana perbezaan dua bentuk fajar iaitu fajar șādiq dan fajar kazib yang sukar dibezakan di seluruh dunia. Walau bagaimanapun situasi di Malaysia lebih mencabar disebabkan faktor tempoh siang dan malam yang sama panjang dan keadaan langit tempatan yang mempunyai kelembapan tinggi dan berawan. Disebabkan cabaran itu, isu penentuan awal waktu solat Subuh sehingga ke hari ini mendapat perhatian para penyelidik ekoran kepentingannya yang melibatkan pelaksanaan ibadah fardu yang utama yakni pengakhiran solat Isyak, awal waktu solat Subuh dan permulaan ibadah puasa.

Di Malaysia, kiraan waktu solat dan penyediaan taqwim waktu solat diselia oleh pihak bertanggungjawab iaitu Jabatan Kemajuan Islam Malaysia (JAKIM) dan jabatan-jabatan mufti negeri dengan menggunakan hitungan formula matematik yang telah mengambil kira keadaan geografi tempatan dan astronomi seperti latitud dan longitud serta sudut altitud. Untuk menetapkan awal waktu solat Subuh, penentuannya adalah berdasarkan fenomena terbitnya 
fajar șādiq sebagaimana telah disepakati oleh para ulama yang mana pada ketika itu, matahari berada pada sudut altitud tertentu.

Berdasarkan realiti semasa, nilai altitud matahari yang digunakan seluruh negeri di Malaysia untuk waktu solat Subuh adalah $-20^{\circ}$ di bawah ufuk kecuali di negeri Kelantan yang menggunakan $-19^{\circ}$ di bawah ufuk. Rentetan daripada penggunaan nilai terbabit dalam penyusunan taqwim waktu solat hanya secara teoretikal tanpa bersandar hasil cerapan yang kukuh terhadap perubahan kecerahan langit, serta akibat ketidakseragaman penerapan nilainya di negeri-negeri Malaysia, maka penyelidikan bagi penilaian semula perlu dibuat untuk menyemak nilai altitud yang terbaik iaitu bukan sahaja mematuhi ketetapan hukum syarak malah kukuh secara saintifik.

\section{TINJAUAN LITERATUR}

Penyelidikan dan penulisan mutakhir berkaitan isu penentuan awal waktu solat Subuh dalam literatur semasa dapat dibahagikan kepada dua kategori iaitu, pertama, kajian kualitatif dan kedua, kajian kuantitatif. Kajian kualitatif dapat dilihat lebih membincangkan isu ini secara teoretikal dan kurang melibatkan pengambilan data-data cerapan di lapangan, manakala kajian kuantitatif membincangkan isu ini secara empirikal dengan melibatkan pengumpulan dan penganalisaan data-data cerapan.

Antara beberapa kajian kualitatif yang meneliti isu ini adalah seperti yang dikemukakan oleh Nurul Asikin Che Daud, ${ }^{1}$ Raihana

1 Nurul Asikin Che Daud et. al., "Towards the unification of twilight parameters for determination of Fajr and Isha in Malaysia." https:// www.mygeoportal.gov.my/ms/towards-unification-twilightparameter-determination-fajr-and-isha-malaysia, dicapai pada 25 April 2019. 
Abdul Wahab, ${ }^{2}$ Nurulhuda Ahmad Zaki, ${ }^{3}$ Susiknan Azhari, ${ }^{4}$ Nur Nafhatun et al., ${ }^{5}$ Nugroho Eko Atmanto, ${ }^{6}$ Moh. Afif Amrullah, ${ }^{7}$ Mohd Odeh, ${ }^{8}$ Abdullah Misnid, ${ }^{9}$ Thomas Djamaluddin ${ }^{10}$ dan Mohd Saleh Mohd@Ahmad. ${ }^{11}$

2 Raihana, A.W, Norihan, K., Mutafa, M.H., "Issues on Determination of-Accurate Fajr and Dhuha Prayer Times According to Fiqh and Astronomical Perspectives in Malaysia: A Bibliography Study," (Conference Proceedings Bali, Indonesia, 13-14 October 2016).

3 Nurul Huda Ahmad Zaki et al., "Penentuan Waktu Solat Subuh Menggunakan Rubu'Mujayyab di Malaysia," Jurnal Fiqh, vol. 11 (2014), 97-118; Nurul Huda Ahmad Zaki et al., "Modern and Traditional Calculation Method in the Determination of Prayer Times in Malaysia: Analysis of Accuracy Comparison," Journal of Research in Islamic Studies, vol. 1, no. 2 (2014), h. 31-34.

4 Susiknan Azhari, "Awal Waktu Salat Subuh di Dunia Islam,” (Kertas Kerja, Persidangan Penyatuan Awal Waktu Salat Subuh, Fakultas Syari'ah dan Hukum UIN Alauddin, Makassar, 2013).

5 Nur Nafhatun et al., "Background Theory of Twilight in Isha'and Subh Prayer Times," dalam Dimensi Penyelidikan Astronomi Islam, ed. Saadan Man et al. (Kuala Lumpur: Jabatan Fiqh dan Usul, Akademi Pengajian Islam, Universiti Malaya, 2013), 121-132.

$6 \quad$ Nugroho Eko Atmanto, "Relevansi Konsep Fajar dan Senja dalam Kitab al-Qanun al-Mas'udi bagi Penetapan Waktu Salat Isya' dan Subuh," Jurnal Analisa, vol. 19, no. 1 (2012), 95-105.

7 Moh Amrullah, "Penentuan Awal Waktu Shalat Subuh Menurut Departemen Agama dan Aliran Salafi: Sebuah Kajian Falakiyah," Jurnal Hukum dan Syariah, vol. 2, no. 2 (2011), 120-134.

8 Muhammad Shawkah Odeh. "Ishkāliyyat Falākiyyah wa Fiqhiyyah Hawla Taḥdīd Mawāqīt al-Șalāt." http://www.icoproject.org/pdf/ Salat_Problems_2010.pdf., dicapai pada 25 April 2019.

9 'Abd Allāh al-Misnid, "Mushkilah Taḥdīd Waqt al-'Ishā’ wa al-Fajr fī al-Manāṭiq al-Jugrafiyyah al-Mutațarrifah Makāniyyan wa Mawāqiṭ al-Șalāh li Ruwad al-Fadā' al-Muslimīn.” http://www.icoproject.org/ pdf/almisnid_2010.pdf., dicapai pada 25 April 2019.

10 "Waktu Subuh ditinjau dari dalil syar'i dan astronomi," Thomas Djamaludin, 2010, diakses daripada http://tdjamalud-din. wordpress. com/2010/04/15/waktu-shubuh-ditinjau-secara-astronomi-dansyari.

11 Mohd Saleh Mohd@Ahmad, "Penentuan Waktu Solat Menurut Fiqh" (Kertas kerja, Konvensyen Falak Selangor 2007, Kolej Islam Sultan Alam Shah, Klang, Selangor, 20-21 Julai 2007), h. 5. 
Manakala, antara kajian kuantitatif yang menyelidik isu penentuan awal waktu solat Subuh secara eksperimental dapat ditelaah dalam beberapa kajian semasa, antaranya ialah Norihan Kadir, ${ }^{12}$ Nihayatur Rohmah, ${ }^{13}$ Abdul Qadir Abid, ${ }^{14}$ Muhammad Shamim Shukor, ${ }^{15}$ A.H. Hassan, ${ }^{16}$ Dhani Herdiwijaya, ${ }^{17}$ Abdullah

12 Norihan Kadir, "Penilaian Semula Parameter Penentuan Awal Waktu Solat Subuh di Malaysia dari Perspektif Astronomi Islam," (Disertasi Sarjana, Jabatan Fiqh dan Usul, Akademi Pengajian Islam, Universiti Malaya, 2017), h. ii.

13 Rohmah, N., "The Effect of Atmospheric Humidity Level to the Determination of Islamic Fajr/Morning Prayer Time and Twilight Appearance," Journal of Physics: Conference Series, vol. 771, no. 1 (2016), 12-48.

14 "Abd al-Qādir "Abid, "Tahdid Maw'id Hulul al-Fajr al-Ṣādiq fĩ alUrdūn bi al-Rasd al-Falāk al-Mubāshir bi al-"Ayn al-Mujarradah," al-Majallah al-Urdūniyyah fì al-Dirāsah al-Islämiyyah, vol. 11, no. 2 (2015), h. 249-264.

15 Muhammad Shamim Shukor \& Mohd Zambri Zainuddin, "Perbandingan Metodologi Kajian Penentuan Masuknya Fajar Sadiq dan Hilangnya Syafaq Ahmar: Kajian Kecerahan Langit," Jurnal Falak, no. 1 (2015), 133-139; Muhammad Shamim Shukor et al., "Kajian Kecerahan Langit di Malaysia," dalam Dimensi Penyelidikan Astronomi Islam, ed. Saadan Man et al. (Kuala Lumpur: Jabatan Fiqh dan Usul, Akademi Pengajian Islam, Universiti Malaya, 2013), 83.

16 Hassan, A.H. et al., "Naked Eye Observations for Morning Twilight at Different Sites in Egypt," NRIAG: Journal of Astronomy and Geophysics, vol. 3, no. 1 (2014), 23-26.

17 Herdiwijaya, D., "Implications of Twilight Sky Brightness Measurements on Fajr Prayer and Young Crescent Observation," (Proceeding 7th International Conference on Physics and Its Applications, Solo, Indonesia, 16-17 September 2014), 26-29. 
Misnid, ${ }^{18}$ Siti Asma' Mohd Nor et al., ${ }^{19}$ Nur Nafhatun ${ }^{20}$ dan Nazhatulshima Ahmad et al. ${ }^{21}$

Berdasarkan beberapa kajian lepas itu, dapat diperhatikan bahawa penentuan awal waktu solat Subuh dengan menggunakan data-data cerapan terhadap kecerahan langit fajar berdasarkan lokasi Malaysia Timur masih lagi kurang diberi perhatian. Melihat kelangkaan itu, kajian ini tampil membentangkan data-data cerapan yang diperlukan dan pengumpulan data dibuat di Pantai Bak-bak, Kudat, Sabah.

\section{KERANGKA REFLEKSI}

Kajian Yetim ${ }^{22}$ dan Gardner $^{23}$ menunjukkan betapa pentingnya suatu kerangka teori dan konsep distruktur secara sistematik dalam reka bentuk penyelidikan bagi membolehkan fungsi refleksi diketengahkan. Fungsi refleksi membantu para pengkaji menyemak secara berpandu aspek kekurangan dan kelebihan penyelidikan yang dilaksanakan dari peringkat awal hingga akhir kajian. Langkah ini memudahkan mana-mana penyelidikan susulan selepas itu membuat penambahbaikan mendapatkan hasil yang lebih baik

18 "Abd Allāh al-Misnid. "Taḥdīd Waqt Dukhūl Șalāh al-Fajr "Amaliyyan bi Manțaqah al-Qāșim.” http://www.icoproject.org/pdf/ almisnid_2012.pdf., dicapai pada 25 April 2019.

19 Siti Asma' Mohd Nor \& Zainuddin, M. Z., "Sky Brightness for Determination of Fajr and Isha Prayer by Using Sky Quality Meter," International Journal of Scientific \& Engineering Research, vol. 3, no. 8 (2012), h. 1-3.

20 Nur Nafhatun Mohd Shariff, "Sky Brightness at Twilight: Detectors Comparisan between Human Eye and Electronic Devise for Isha \& Subh from Islamic and Astronomical Considerations," (Disertasi Sarjana, Jabatan Pengajian Sains dan Teknologi, Fakulti Sains, Universiti Malaya, Kuala Lumpur, 2010).

21 Nazhatulshima Ahmad et al., "Kajian Kecerahan Langit di Ufuk Senja dan Fajar," Jurnal INSTUN, vol. 1, no. 2 (2007), h. 51.

22 Yetim, Fahri, "Supporting and Understanding Reflection on Persuasive Technology Through A Reflection Schema," (Paper presented, International Conference on Persuasive Technology, Springer, Cham, 2019), 43-51.

23 Gardner, Fiona, "Critical Reflection in Community-Based Evaluation," Qualitative Social Work, vol. 2, no. 2 (2003), 197-212. 
dalam semua aspek, terutamanya segi perkaedahan, proses kerja dan hasil kajian. ${ }^{24}$ Untuk itu, dalam kajian ini, perspektif integrasi ilmu disusun sebagai kerangka refleksi dan ia mengintegrasikan perspektif Syariah dan astronomi.

\section{Perspektif Syariah}

Waktu solat Subuh merupakan sebahagian daripada waktu yang telah ditetapkan syarak untuk pelaksanaan ibadah solat fardu iaitu solat Subuh atau dinamakan juga sebagai solat Fajar. Dari sudut bahasa berdasarkan Lisan al-Arab, perkataan Subuh (الصبح) bermaksud permulaan siang atau fajar. ${ }^{25}$ Fajar (الفجر) pula didefinisikan sebagai cahaya Subuh iaitu cahaya kemerahmerahan yang muncul setelah kegelapan malam. Terdapat dua jenis fajar dengan salah satu daripadanya merupakan cahaya yang memanjang ke atas seperti ekor serigala (Zanab al-Sirhan) iaitu fajar kazib atau fajar palsu (false dawn) manakala fajar jenis kedua pula adalah fajar șādiq atau fajar benar (true dawn) yang cahayanya berserak di sepanjang ufuk dan ia menjadi tanda bagi orang yang berpuasa diharamkan makan dan minum serta tanda masuknya waktu solat Subuh. ${ }^{26}$

Hal ini turut diterangkan dalam firman Allah SWT:

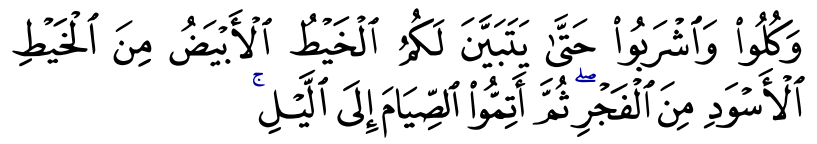

Terjemahan: "Dan makan minumlah hingga terang bagimu benang putih dari benang hitam, iaitu fajar. Kemudian sempurnakanlah puasa itu sehingga

24 Lihat juga dalam Liebert, Wolfgang \& Jan C. Schmidt, "Towards A Prospective Technology Assessment: Challenges and Requirements for Technology Assessment in the Age of Technoscience," Poiesis \& Praxis, vol. 7, no. 1-2 (2010), 99-116.

25 Abū al-Fadl Jamāl al-Dīn Muḥammad Ibn Mukarram al-Anșārī Ibn Manẓūr, Lisān al- 'Arab, vol. 5 (Bayrūt: Dār Șadr, 1994), 263.

26 Abū al-Fadl Jamāl al-Dīn Muhammad Ibn Mukarram al-Anșārī Ibn Manẓūr, Lisān al- 'Arab, vol. 5, 45, 47. 
tibanya malam.”

(Surah al-Baqarah, 2: 187)

Merujuk kepada ayat di atas, Ibn Jarir al-Tabari menerangkan bahawa firman Allah SWT, iaitu min al-fajr atau terbit fajar bermaksud ketika jelas bagi kalian benang putih dari benang hitam yang mana adalah sebahagian dari fajar, bukan keseluruhan fajar. ${ }^{27}$ Al-Qurțūbī pula menjelaskan bahawa yang dinamai fajar (șädiq) itu benang, kerana yang muncul berupa warna putih terlihat memanjang seperti benang. Ibn Taymiyyah menjelaskan bahawa dinamakan putihnya siang dengan merujuk benang putih dan hitamnya malam dengan merujuk benang hitam adalah bagi menunjukkan bahawa fajar yang terbit adalah awal permulaannya adalah berwarna putih dan perbezaannya dengan warna hitam adalah sangat nipis kerana benang itu sendiri adalah tipis. AlZamakhsyari juga menghuraikan bahawa yang dimaksudkan dengan istilah al-khayt al-abyad ialah awal permulaan kelihatan fajar yang membentang di ufuk seperti benang yang dibentang. ${ }^{28}$

Dalam al-Quran, terdapat beberapa ayat yang lain turut mengungkapkan tentang waktu solat Subuh, antaranya firman Allah SWT:

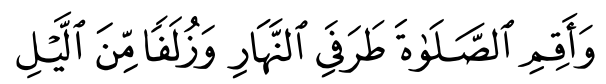

Terjemahan: "Dan dirikanlah solat pada dua bahagian siang (pagi dan petang), dan pada waktu-waktu yang berhampiran dengannya dari waktu malam."

(Surah Hūd, 11: 114)

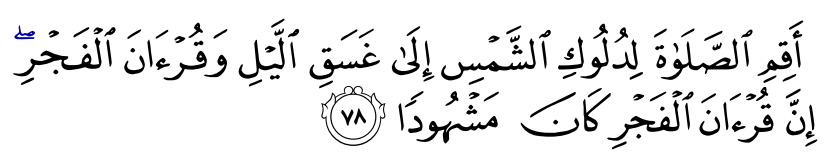

27 Ibrāhīm Muhammad al-Ṣabīhị̂, Ṭulū' al-Fajr al-Sadīq bayna Tahdīd al-Qur'ān wa Iṭlāq al-Lughah (Riyāḍ: Maktabah al-Mālik Fahd, 2007), 40-42.

28 Perbahasan para ulama dalam hal ini selanjutnya, lihat Ibrāhīm Muḥammad al-Șabīḥì, Țulū' al-Fajr al-Ṣadīq bayna Taḥdīd alQur'ān wa Ițlāq al-Lughah, 48. 
Terjemahan: "Dirikanlah solat ketika gelincir matahari hingga waktu gelap malam, dan (dirikanlah) solat Subuh. Sesungguhnya solat Subuh itu adalah disaksikan (keistimewaannya)."

(Surah al-Isrā', 17: 78)

Dalam satu hadis yang diriwayatkan dari Abdullah bin Amru bin al-'Ash RA, bahawasanya Rasulullah SAW bersabda sepertimana berikut:

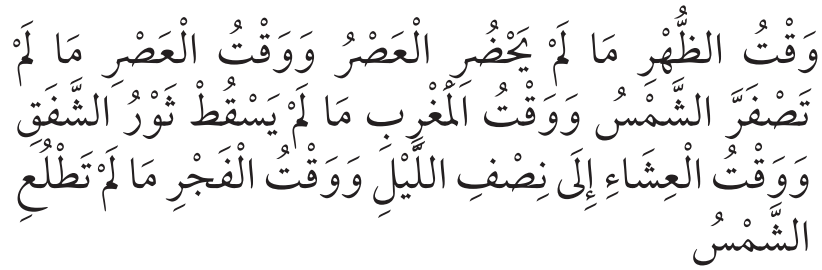

Terjemahan: "Waktu Zohor adalah apabila gelincir matahari hingga bayangan menyamai panjang orangnya, selagi mana 'Asar belum tiba, waktu 'Asar adalah selama matahari belum menguning, waktu Maghrib adalah selama mega merah belum menghilang, waktu Isya' adalah hingga separuh malam yang tengah, dan waktu solat Subuh adalah sejak terbit fajar selama matahari belum terbit. Apabila matahari telah terbit, maka janganlah kamu lakukan solat, kerana matahari itu muncul di antara dua tanduk syaitan (HR Muslim)." ${ }^{29}$

Hadis di atas ialah antara beberapa hadis yang menjadi rujukan untuk menetapkan waktu bagi ibadah wajib solat lima waktu yang ditentukan mengikut kedudukan matahari termasuklah untuk waktu solat Subuh. Dalam hadis yang lain memperincikan fenomena fajar kepada dua jenis:

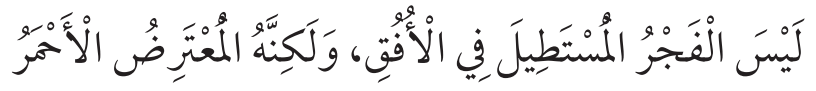

Terjemahan: "Fajar itu bukanlah garis mening-

29 Riwayat Muslim, Șaḥiḥ Muslim, no. hadith 220, jilid-5, diakses daripada laman sesawang Sunnah.com, https://sunnah.com/muslim/5 
gi di ufuk tetapi ia adalah melintang di berwarna merah." 30

Dari perspektif fiqh, fenomena fajar kazib dan fajar șādiq membawa kesan hukum yang berbeza. Berdasarkan keterangan daripada beberapa nas di atas dan penjelasan para ulama, jelas bahawa fajar kazib tiada kaitan dengan hukum syarak, manakala hanya fajar șâdiq yang relevan dengan hukum syarak dan ia disepakati oleh para fuqaha sebagai tanda berakhir waktu solat fardu Isyak, masuknya waktu solat Subuh dan bermulanya ibadah puasa. $^{31}$

Dalam Mesyuarat Jawatankuasa Fatwa Negeri Melaka Bil. $3 / 2012$ yang bersidang pada 19 Zulkaedah $1433 \mathrm{H}$ bersamaan dengan 5 Oktober 2012, ${ }^{32}$ perbezaan fenomena fajar kazib dan fajar șädiq telah dibincangkan dan mesyuarat telah membuat keputusan seperti berikut:

Fajar kazib dapat dikenali berdasarkan ciri-ciri berikut:

i) Merupakan bayangan cahaya yang kelihatan di ufuk timur.

ii) Memancar dari bawah menjulang ke atas di tengah-tengah langit.

iii) Cahayanya terpisah dari ufuk iaitu ada kegelapan antaranya dan ufuk.

iv) Pada kedua-dua sisinya (kiri dan kanan) adalah kelihatan gelap dan warna cahayanya berwarna putih yang bercampur dengan hitam seumpama ekor serigala.

v) Cahayanya malap dan belum memancarkan rona kemerahmerahan dan ia kelihatan berjurai-jurai.

vi) Cahayanya muncul seketika, kemudian ia menjadi gelap.

Ciri-ciri fajar șādiq ialah seperti berikut:

30 Riwayat Abū Dawud dan al-Tirmidhi, no. hadith 16234. Lihat Aḥmad Ibn Hanbal, Musnad Imām Aḥmad Ibn Hanbal, vol. 12 (Qāhirah: Dār al-Hadīth,1995), 515.

31 Wahbah al-Zuhaylī, al-Fiqh al-Islāmī wa Adillatuh, vol. 1 (Dimashq: Dār al-Fikr, 2004), 664.

32 Diakses daripada http://www.e-fatwa.gov.my/fatwa-negeri/tafsiranfajar-sadiq-dalam-penentuan-waktu-subuh-menurut-syarak. 
i) Cahaya yang muncul selepas fajar kazib.

ii) Cahayanya berwarna putih dan kelihatan mendatar mengikut garis lintang ufuk timur dan perlahan-lahan menyebar naik ke langit.

iii) Tidak terdapat kegelapan antara cahaya tersebut dan ufuk.

iv) Cahayanya bertambah cerah dan ia berakhir setelah matahari muncul perlahan-lahan di ufuk timur

\section{Perspektif Astronomi}

Dari perspektif astronomi, fenomena fajar berlaku pada waktu pagi (morning twilight/dawn). Ia adalah kesan serakan cahaya matahari yang berlaku sebelum matahari terbit. Matahari yang berada di bawah ufuk memantulkan cahayanya ke ufuk langit di sekitarnya. Cahaya ini kemudian diserap oleh wap-wap air dalam atmosfera menyebabkan ia tersebar dalam bentuk serakan. Perubahan kei cerahan langit berlaku apabila sudut junaman matahari di bawah ufuk berubah. Kesan ini semakin kelihatan apabila matahari berada 18 darjah di bawah ufuk. Selain itu, terdapat pelbagai faktor yang menyumbang kepada perbezaan kecerahan langit. Antara faktor tersebut adalah serakan cahaya matahari dan bulan. Dalam astronomi, fenomena fajar dibahagikan kepada tiga peringkat: ${ }^{33}$

\section{a. Fajar Awam (Civil Dawn)}

Fajar awam merujuk kepada serakan cahaya ketika matahari hampir terbit di ufuk sehingga matahari berada $6^{\circ}$ di bawah ufuk. Ufuk langit pada ketika itu diterangi oleh cahaya matahari dengan sinaran yang kuat dan objek-objek di tempat lapangan terbuka masih lagi jelas kelihatan bentuknya. Manakala bintang yang boleh dilihat hanyalah sebahagian bintang yang terang sahaja.

33 Yallop, B. D. \& C. Y. Hohenkerk, "A Note on Sunrise," Sunset and Twilight Times and on the Illumination Conditions During Twilight: Astronomical Information Sheet (Cambridge: HM Nautical Almanac Office. No. 7, 1996), http://astro.ukho.gov.uk/nao/aisinfo/ais007.pdf dicapai pada 24 April 2019. 


\section{b. Fajar Kelautan (Nautical Dawn)}

Fajar kelautan berlaku ketika matahari berada antara $6^{\circ}$ sehingga $12^{\circ}$ di bawah ufuk sebelah pagi. Dalam keadaan ini, ufuk langit masih boleh kelihatan, namun objek-objek di tempat lapang adalah samar bentuknya. Manakala bintang yang boleh dilihat adalah semua bintang yang terang.

\section{c. Fajar Falak (Astronomical Dawn)}

Fajar falak berlaku ketika matahari berada pada kedudukan antara $12^{\circ}$ sehingga $18^{\circ}$ di bawah ufuk sebelah pagi. Pada peringkat ini keadaan ufuk sudah hampir sempurna gelap tetapi wujud cahaya berwarna kemerah-merahan sehingga peringkat akhir fajar. Dalam keadaan ini juga, objek-objek di tempat lapang tidak kelihatan bentuknya. Semua bintang baik yang terang mahu pun yang samar jelas dapat dicerap. ${ }^{34}$

Sebagaimana dinyatakan, keterangan nas secara terang menunjukkan bahawa bermulanya waktu solat Subuh adalah ketika fajar șādiq terbit di ufuk timur. Dari sudut kiraan matematik, keadaan terbabit merujuk kepada kedudukan matahari lebih kurang $18^{\circ}$ di bawah ufuk. Dalam realiti semasa, para fuqaha bersetuju supaya awal waktu solat Subuh ditetapkan ketika matahari di kedudukan terkebawah daripada $-18^{\circ}$ di bawah ufuk. Terdapat pihak yang menetapkan $19^{\circ}$ dan ada pula yang menetapkan $20^{\circ}$ di bawah ufuk. Bagi pihak yang menetapkan $19^{\circ}$ jarak zenit matahari yang diambil untuk perhitungan adalah $109^{\circ}$ iaitu $\mathrm{ZS}=$ $109^{\circ}$. Manakala bagi pihak yang menetapkan $20^{\circ}$ jarak zenit yang digunakan untuk perhitungan adalah $110^{\circ}$ iaitu $\mathrm{ZS}=110^{\circ} .{ }^{35}$

Rajah di bawah menerangkan kedudukan matahari $20^{\circ}$ di bawah ufuk ketika masuk waktu solat Subuh.

34 Baharrudin Zainal, Pengenalan Ilmu Falak (Kuala Lumpur: Dewan Bahasa dan Pustaka, 2002), 93-94.

35 Diakses daripada http://www.e-solat.gov.my/web/index1. php?id=55\&type=A. 


\section{Rajah 1: Kedudukan Matahari di Bawah Ufuk Ketika Masuk Waktu Solat Subuh ${ }^{36}$}

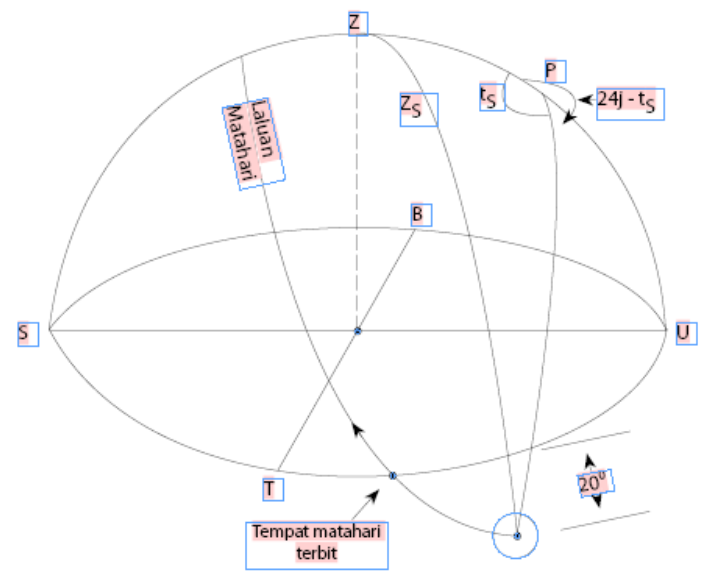

Sumber: Jabatan Mufti Negeri Selangor (2005).

Berdasarkan rumus trigonometri, $\mathrm{t}_{\mathrm{s}}$ ditentukan dengan formula sebagai:

$$
\text { tSubuh }=\cos ^{-1}\left[\frac{\cos Z_{\text {Subuh }}-\sin \delta \sin \phi}{\cos \delta \cos \phi}\right]
$$

Kemudian,

Waktu masuk solat Subuh $=$ Waktu matahari Istiwa' $-\mathrm{t}_{\mathrm{s}}$

Waktu solat Subuh berakhir apabila matahari terbit iaitu pinggir atas matahari berada di ufuk timur.

Pada masa kini, penetapan darjah kedudukan matahari di bawah ufuk bagi menentukan masuknya waktu solat Subuh pada peringkat antarabangsa dapat diterangkan secara ringkas melalui jadual di bawah:

36 Jabatan Mufti Negeri Selangor, Kaedah Penentuan dan Pengiraan Waktu Solat (Shah Alam: Jabatan Mufti Negeri Selangor, 2005), 24. 
Jadual 1: Altitud Matahari Yang Digunakan di Peringkat Antarabangsa untuk Penentuan Awal Waktu Solat Subuh ${ }^{37}$

\begin{tabular}{lc}
\hline \multicolumn{1}{c}{ Organisasi } & Altitud Matahari \\
\hline Islamic Society of North America & $-15^{\circ}$ \\
Muslim World League & $-18^{\circ}$ \\
Umm al-Qura, Makkah & $-18.5^{\circ}$ \\
Egyptian General Authority of Survey & $-19.5^{\circ}$ \\
Badan Hisab Rukyat Departmen & $-20^{\circ}$ \\
Agama, Indonesia & $-20^{\circ}$ \\
Malaysia & \\
\hline
\end{tabular}

Sumber: Nur Nafhattun (2013)

Rajah 2: Perspektif Integrasi IImu

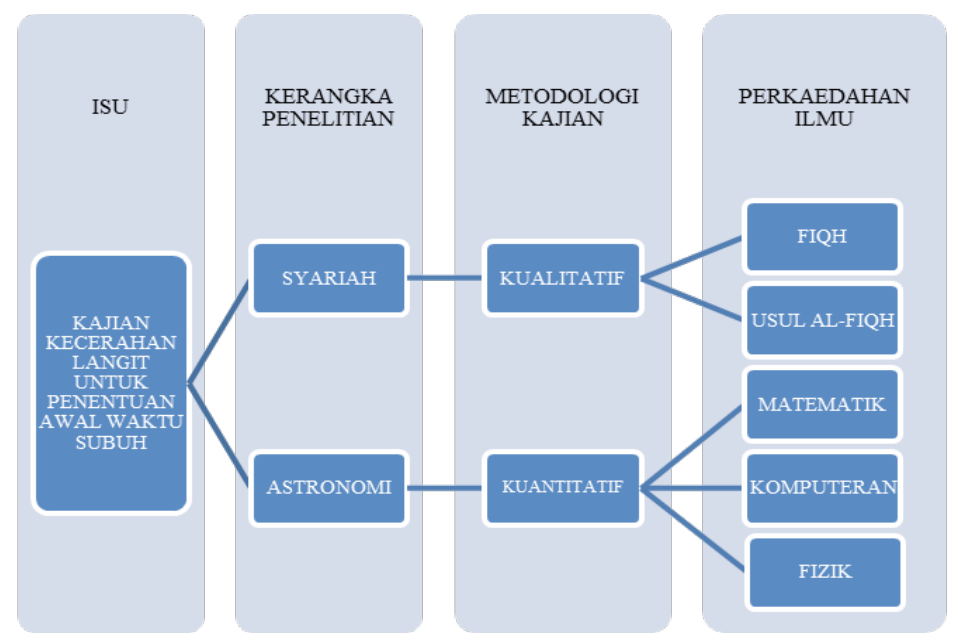

Sumber: Rumusan pengkaji.

Berdasarkan perspektif Syariah dan astronomi yang telah dihuraikan, pengkaji merumuskan perspektifintegrasi ilmu melalui rajah 2 di atas bagi konteks kajian kecerahan langit fajar untuk penentuan awal waktu solat Subuh. Isu pokok adalah berkaitan

37 Nur Nafhatun et al., "Background Theory of Twilight in Isha' and Subh prayer Times," 121-132. 
penentuan awal waktu solat Subuh berasaskan fenomena langit fajar șādiq yang terletak dalam aturan ilmu Syariah. Dari perspektif fiqh, adalah jelas bahawa apabila terbit fajar șādiq maka berlakulah ketetapan hukum syarak berkaitan ibadah fardu iaitu berakhirnya waktu solat Isyak dan bermulanya kewajipan solat Subuh dan ibadah puasa. Bagaimanapun, hakikat sebenar fenomena fajar $s ̧ \bar{a} d i q$ hanya diterangkan secara kualitatif. Dari perspektif usul alfiqh, pendalilan fajar șädiq adalah jelas bersandar nas al-Quran seperti yang dijelaskan pada ayat 78 dalam surah al-Isra' dan ayat 187 dalam surah al-Baqarah. Nas menunjukkan secara kukuh (qat ‘̂̀) bahawa fajar șādiq adalah asas penentuan awal waktu solat Subuh. Namun, aspek kesamaran (zannī) terletak kepada penjelasan nas berkaitan fenomena terbabit yang diterangkan juga secara kualitatif. Dari perspektif perkaedahan, maka cerapan mata kasar (naked-eye) terhadap fenomena fajar șādiq adalah kaedah asas (daruri $)$ mengikut pendekatan Syariah, manakala pendekatan astronomi yang menaplikasikan sains dan teknologi seperti instrumen SQM-LU berperanan penting sebagai pemudah dan pelengkap kepada cerapan mata kasar. Dengan ilmu matematik, maka kedudukan dan gerakan matahari dapat dihitung dengan bantuan perisian komputer. Demikian juga dalam pengambilan data cerapan, perisian komputer yang disertakan bersama SQMLU memudahkan aktiviti pemerolehan data. Adapun komponen ilmu fizik adalah amat penting bagi memastikan teknik dan prosedur pengambilan dan analisis data cerapan fajar șādiq dibuat secara sistematik dan konsisten.

\section{METODOLOGI KAJIAN}

Bagi pengumpulan data, pengkaji telah menjalankan kajian lapangan di Pantai Bak-bak di Sabah yang terletak pada koordinat $6^{\circ} 56$ ' 48.0" U $116^{\circ} 50^{\prime}$ 24.7" T. Lokasi ini dipilih berdasarkan kedudukannya yang menghadap ufuk timur dan berpotensi kurang gangguan cahaya. Tarikh cerapan yang dipilih adalah ketika awal bulan qamari iaitu antara 1 hingga 13 qamari bagi mengelakkan gangguan cahaya bulan penuh. Peralatan utama yang digunakan untuk perolehan data ialah Sky Quality Meter jenis LENS USB (SQM-LU). Instrumen ini digunakan untuk mengukur kecerahan langit waktu fajar, dan mudah diaplikasikan semasa cerapan dijalankan. Ia diletakkan di atas tapak yang mempunyai sudut tuju 
yang berbeza iaitu $10^{\circ}, 30^{\circ}$ dan $50^{\circ}$ (lihat Rajah 2) dan bahagian pengesan cahayanya (sensor) perlu dihalakan ke arah azimut matahari terbit di ufuk (lihat rajah 3). Kemudian bacaan kecerahan langit direkodkan secara terus ke dalam komputer.

\section{Rajah 3: SQM-LU}

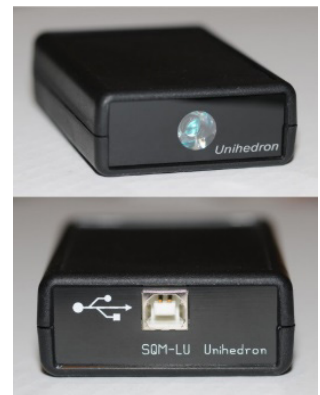

Rajah 4: Tapak SQM mengikut sudut $10^{\circ}, 30^{\circ}$ dan $50^{\circ}$

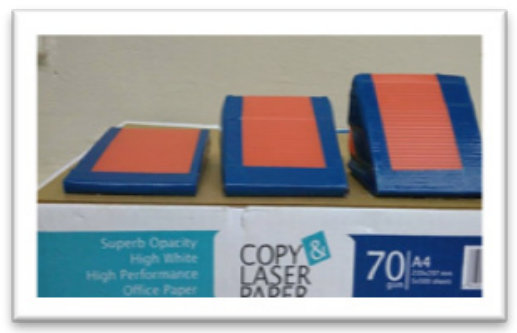

Rajah 5: Susun atur instrumen semasa cerapan menghadap matahari terbit

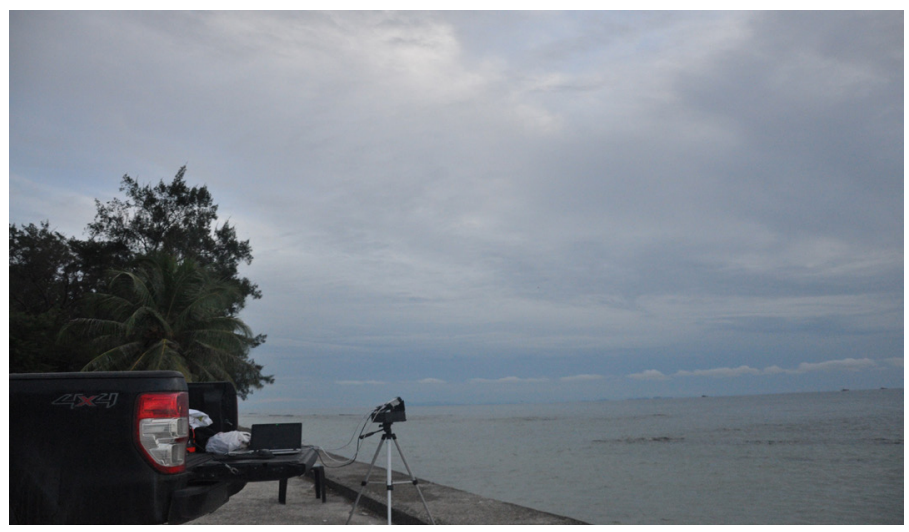


Data yang diperolehi kemudiannya dialihkan ke dalam bentuk jadual untuk diproses. Berdasarkan jadual tersebut, graf diplot untuk menentukan awal waktu solat Subuh yang diperoleh apabila graf mula menunjukkan tren mendatar dan kemudian menurun. Seterusnya, perisian MoonC digunakan bagi mendapatkan maklumat kedudukan ketinggian matahari semasa bacaan graf mula menurun untuk waktu solat Subuh. Keputusan yang diperoleh daripada graf seterusnya dibandingkan dengan takwim solat bagi waktu solat Subuh daripada Jabatan Kemajuan Islam Malaysia (JAKIM). Bagi melihat perubahan kecerahan langit pula, data mula diambil sekitar 15 minit sebelum masuknya waktu solat Subuh menurut takwim waktu solat tempatan sehingga masuk waktu syuruk iaitu terbit matahari.

\section{KEPUTUSAN DAN PERBINCANGAN}

Kajian ini telah dilaksanakan pada bulan September 2017 dan setakat ini baru 3 set data diperoleh iaitu pada tarikh 29 dan 30 September serta 1 Oktober 2017 iaitu bersamaan 8 hingga $10 \mathrm{Mu}-$ haram 1439 Hijrah. Berikut adalah hasil data dan analisis graf kecerahan langit dan altitud matahari melawan masa bagi menunjukkan perubahan kecerahan langit sekali gus menentukan fajar șādiq yang menandakan awal masuk Subuh.

\section{SET DATA SATU}

Tarikh

Hari

Waktu solat Subuh

Waktu syuruq

Keadaan langit

Keadaan ufuk
: 29/09/2017

: Jumaat

: 4.44 pagi

: 6.00 pagi

: Berawan dan cerah

: Berawan

Jadual 2: Data Kecerahan Langit Fajar Pada 29/09/2017

\begin{tabular}{cccc}
\hline & \multicolumn{3}{c}{ Kecerahan langit (mag/arkasaat $\left.{ }^{2}\right)$} \\
& \multicolumn{3}{c}{ sudut tuju SQM-LUikut } \\
\hline Masa & SQM-LU & SQM-LU & SQM-LU \\
$( \pm 1$ saat $)$ & $\left(10^{\circ}\right)$ & $\left(30^{\circ}\right)$ & $\left(50^{\circ}\right)$ \\
\hline $04: 30: 00$ & 21.73 & 21.61 & 21.7
\end{tabular}




$\begin{array}{lccc}\text { 04:31:00 } & 21.71 & 21.6 & 21.71 \\ 04: 32: 00 & 21.71 & 21.6 & 21.71 \\ 04: 33: 00 & 21.72 & 21.6 & 21.69 \\ 04: 34: 00 & 21.72 & 21.61 & 21.7 \\ \text { 04:35:00 } & 21.7 & 21.61 & 21.69 \\ 04: 36: 00 & 21.7 & 21.61 & 21.69 \\ 04: 37: 00 & 21.7 & 21.61 & 21.68 \\ 04: 38: 00 & 21.7 & 21.61 & 21.68 \\ 04: 39: 00 & 21.69 & 21.6 & 21.65 \\ 04: 40: 00 & 21.69 & 21.59 & 21.65 \\ 04: 41: 00 & 21.71 & 21.56 & 21.64 \\ 04: 42: 00 & 21.71 & 21.56 & 21.6 \\ 04: 43: 00 & 21.68 & 21.51 & 21.6 \\ 04: 44: 00 & 21.68 & 21.51 & 21.59 \\ 04: 45: 00 & 21.66 & 21.49 & 21.59 \\ 04: 46: 00 & 21.64 & 21.47 & 21.57 \\ 04: 47: 00 & 21.61 & 21.44 & 21.56 \\ 04: 48: 00 & 21.58 & 21.41 & 21.55 \\ 04: 49: 00 & 21.55 & 21.38 & 21.53 \\ 04: 50: 00 & 21.53 & 21.35 & 21.52 \\ 04: 51: 00 & 21.52 & 21.34 & 21.51 \\ 04: 52: 00 & 21.51 & 21.34 & 21.52 \\ 04: 53: 00 & 21.5 & 21.34 & 21.53 \\ 04: 54: 00 & 21.49 & 21.33 & 21.55 \\ 04: 55: 00 & 21.47 & 21.31 & 21.52 \\ 04: 56: 00 & 21.44 & 21.28 & 21.5 \\ 04: 57: 00 & 21.41 & 21.22 & 21.46 \\ 04: 58: 00 & 21.37 & 21.17 & 21.43 \\ 04: 59: 00 & 21.32 & 21.11 & 21.38 \\ 05: 00: 00 & 21.28 & 21.04 & 21.33 \\ 05: 01: 00 & 21.22 & 20.96 & 21.26 \\ 05: 02: 00 & 21.15 & 20.86 & 21.19 \\ 05: 03: 00 & 21.07 & 20.77 & 21.11 \\ 05: 04: 00 & 21.01 & 20.67 & 21.02 \\ 05: 05: 00 & 20.94 & 20.56 & 20.92 \\ 05: 06: 00 & 20.83 & 20.41 & 20.8 \\ 05: 07: 00 & 20.7 & 20.24 & 20.68 \\ 05: 08: 00 & 20.52 & 20.05 & 20.52 \\ 05: 09: 00 & 20.33 & 19.84 & 20.35 \\ 05: 10: 00 & 20.12 & 19.6 & 20.16 \\ 05: 11: 00 & 19.89 & 19.36 & 19.95 \\ 05: 12: 00 & 19.64 & 19.12 & 19.75 \\ 05: 13: 00 & 19.38 & 18.87 & 19.52\end{array}$




\begin{tabular}{cccc} 
05:14:00 & 19.14 & 18.62 & 19.3 \\
05:15:00 & 18.88 & 18.37 & 19.08 \\
05:16:00 & 18.62 & 18.12 & 18.84 \\
05:17:00 & 18.37 & 17.86 & 18.6 \\
05:18:00 & 18.1 & 17.59 & 18.34 \\
05:19:00 & 17.82 & 17.32 & 18.08 \\
05:20:00 & 17.54 & 17.04 & 17.82 \\
\hline
\end{tabular}

\section{Graf 1: Data Kecerahan Langit Fajar Pada 29/09/2017}

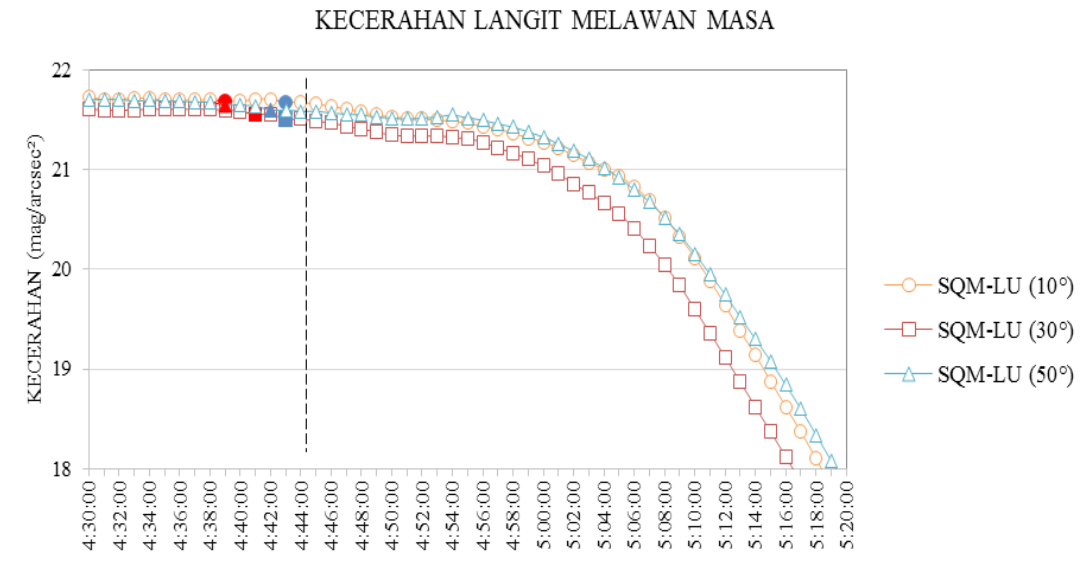

MASA (AM)

\section{Graf 2: Penentuan Fajar Kazib dan Fajar Șādiq Pada} 29/09/2017

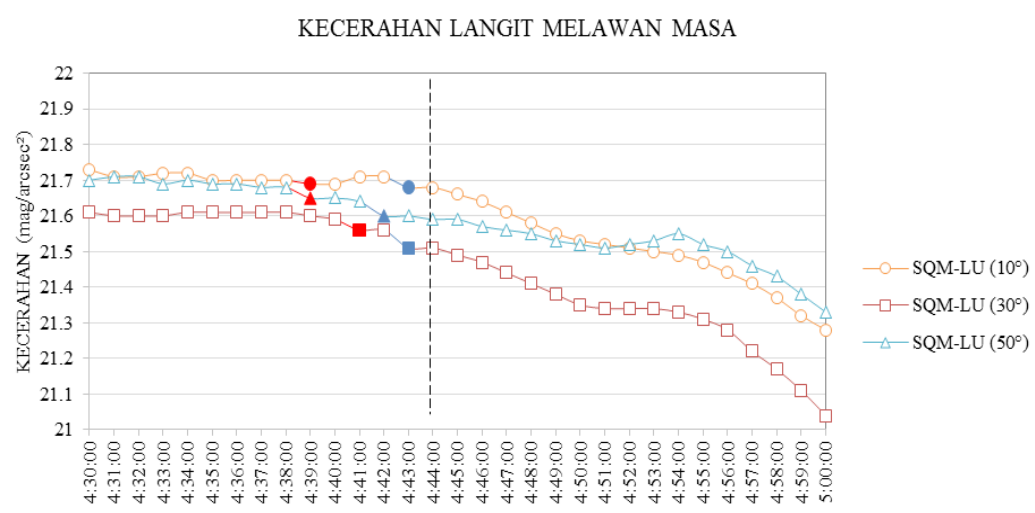

MASA (AM) 
Jadual 3: Analisis Data Kecerahan Langit Fajar Pada 29/09/2017

\begin{tabular}{|c|c|c|c|c|c|c|}
\hline \multicolumn{2}{|c|}{$\begin{array}{l}\text { Waktu Solat } \\
\text { (JAKIM) }\end{array}$} & \multirow[b]{2}{*}{$\begin{array}{c}\text { Sudut } \\
\text { Tuju } \\
\text { SQM-LU }\end{array}$} & \multicolumn{2}{|c|}{ Fajar Kazib } & \multicolumn{2}{|c|}{ Fajar Șādiq } \\
\hline $\begin{array}{l}\text { Masa } \\
(\mathrm{AM})\end{array}$ & $\begin{array}{l}\text { Altitud } \\
\text { Matahari } \\
\left({ }^{\circ}\right)\end{array}$ & & $\begin{array}{l}\text { Masa } \\
(\mathrm{AM})\end{array}$ & $\begin{array}{l}\text { Altitud } \\
\text { Matahari } \\
\left(^{\circ}\right)\end{array}$ & $\begin{array}{l}\text { Masa } \\
(\mathrm{AM})\end{array}$ & $\begin{array}{c}\text { Altitud } \\
\text { Matahari } \\
\left(^{\circ}\right)\end{array}$ \\
\hline \multirow[t]{3}{*}{ 04:44:00 } & -19.915 & $10^{\circ}$ & 04:39:00 & -21.156 & 04:43:00 & -20.163 \\
\hline & & $30^{\circ}$ & 04:41:00 & -20.659 & 04:43:00 & -20.163 \\
\hline & & $50^{\circ}$ & 04:39:00 & -21.156 & 04:42:00 & -20.411 \\
\hline
\end{tabular}

Graf 1 dan 2 di atas menunjukkan fajar șādiq mulai muncul beberapa minit lebih awal sebelum masuknya waktu solat Subuh. Ketika fajar șādiq muncul, altitud matahari ialah $-21.163^{\circ}$ (untuk SQM-LU $10^{\circ}$ dan $30^{\circ}$ ) dan $-20.411^{\circ}$ (untuk SQM-LU 50 ${ }^{\circ}$ ) iaitu masing-masing berbeza sebanyak $\pm 1.163^{\circ}$ dan $\pm 0.411^{\circ}$ daripada nilai altitud $20^{\circ}$ yang digunakan di Malaysia untuk menandakan masuknya waktu solat Subuh. Dari sudut cerapan mata kasar dan kamera DSLR, fajar kazib dan fajar șādiq tidak dapat dikesan kerana keadaan langit dan di ufuk adalah berawan sepanjang cerapan dilakukan.

\section{SET DATA DUA}

Tarikh

Hari

: 30/09/2017

Waktu solat Subuh $\quad: 4.44$ pagi

Waktu syuruq

Keadaan langit

: 6.00 pagi

Keadaan ufuk

: Berawan dan cerah

: Berawan

Jadual 4: Data Kecerahan Langit Fajar Pada 30/09/2017

\begin{tabular}{cccc}
\hline & \multicolumn{3}{c}{ Kecerahan langit (mag/arkasaat ${ }^{2}$ ) mengikut } \\
sudut tuju SQM-LU \\
\hline Masa & SQM-LU & SQM-LU & SQM-LU \\
$( \pm 1$ saat $)$ & $\left(10^{\circ}\right)$ & $\left(30^{\circ}\right)$ & $\left(50^{\circ}\right)$ \\
\hline
\end{tabular}




\begin{tabular}{|c|c|c|c|}
\hline 04:30:52 & 21.18 & 21.01 & 20.86 \\
\hline $04: 31: 52$ & 21.18 & 21.01 & 20.86 \\
\hline $04: 32: 52$ & 21.17 & 20.99 & 20.86 \\
\hline $04: 33: 52$ & 21.17 & 20.99 & 20.85 \\
\hline $04: 34: 52$ & 21.18 & 20.98 & 20.85 \\
\hline $04: 35: 52$ & 21.18 & 20.98 & 20.86 \\
\hline $04: 36: 52$ & 21.18 & 20.98 & 20.86 \\
\hline $04: 37: 52$ & 21.17 & 20.95 & 20.85 \\
\hline 04:38:52 & 21.17 & 20.95 & 20.85 \\
\hline 04:39:52 & 21.17 & 20.96 & 20.84 \\
\hline 04:40:52 & 21.17 & 20.95 & 20.84 \\
\hline 04:41:52 & 21.16 & 20.94 & 20.84 \\
\hline $04: 42: 52$ & 21.16 & 20.94 & 20.82 \\
\hline $04: 43: 52$ & 21.14 & 20.95 & 20.83 \\
\hline $04: 44: 52$ & 21.14 & 20.94 & 20.83 \\
\hline $04: 45: 52$ & 21.15 & 20.94 & 20.82 \\
\hline $04: 46: 52$ & 21.14 & 20.94 & 20.83 \\
\hline $04: 47: 52$ & 21.14 & 20.95 & 20.82 \\
\hline $04: 48: 52$ & 21.13 & 20.95 & 20.82 \\
\hline $04: 49: 52$ & 21.13 & 20.94 & 20.83 \\
\hline $04: 50: 52$ & 21.12 & 20.94 & 20.83 \\
\hline $04: 51: 52$ & 21.13 & 20.92 & 20.82 \\
\hline $04: 52: 52$ & 21.12 & 20.93 & 20.81 \\
\hline $04: 53: 52$ & 21.12 & 20.94 & 20.82 \\
\hline 04:54:52 & 21.11 & 20.92 & 20.82 \\
\hline $04: 55: 52$ & 21.11 & 20.92 & 20.82 \\
\hline $04: 56: 52$ & 21.11 & 20.91 & 20.81 \\
\hline $04: 57: 52$ & 21.11 & 20.91 & 20.81 \\
\hline $04: 58: 52$ & 21.1 & 20.92 & 20.8 \\
\hline $04: 59: 52$ & 21.06 & 20.91 & 20.78 \\
\hline $05: 00: 52$ & 21.05 & 20.88 & 20.75 \\
\hline 05:01:52 & 21.03 & 20.87 & 20.72 \\
\hline $05: 02: 52$ & 20.97 & 20.84 & 20.68 \\
\hline $05: 03: 52$ & 20.9 & 20.78 & 20.63 \\
\hline 05:04:52 & 20.85 & 20.73 & 20.57 \\
\hline $05: 05: 52$ & 20.79 & 20.69 & 20.52 \\
\hline 05:06:52 & 20.71 & 20.61 & 20.46 \\
\hline 05:07:52 & 20.69 & 20.55 & 20.4 \\
\hline 05:08:52 & 20.64 & 20.49 & 20.31 \\
\hline 05:09:52 & 20.57 & 20.44 & 20.22 \\
\hline
\end{tabular}


Jurnal Fiqh, Vol. 16 No. 2 (2019) 253-288

\begin{tabular}{lccc}
$05: 10: 52$ & 20.52 & 20.36 & 20.1 \\
$05: 11: 52$ & 20.43 & 20.26 & 20.22 \\
$05: 12: 52$ & 20.32 & 20.16 & 20.1 \\
$05: 13: 52$ & 20.21 & 20.04 & 19.98 \\
$05: 14: 52$ & 20.07 & 19.91 & 19.85 \\
$05: 15: 52$ & 19.93 & 19.76 & 19.71 \\
$05: 16: 52$ & 19.82 & 19.6 & 19.55 \\
$05: 17: 52$ & 19.64 & 19.45 & 19.4 \\
$05: 18: 52$ & 19.45 & 19.27 & 19.23 \\
$05: 19: 52$ & 19.24 & 19.07 & 19.04 \\
$05: 20: 52$ & 19.03 & 18.87 & 18.85 \\
\hline
\end{tabular}

\section{Graf 3: Data Kecerahan Langit Fajar Pada 30/09/2017}

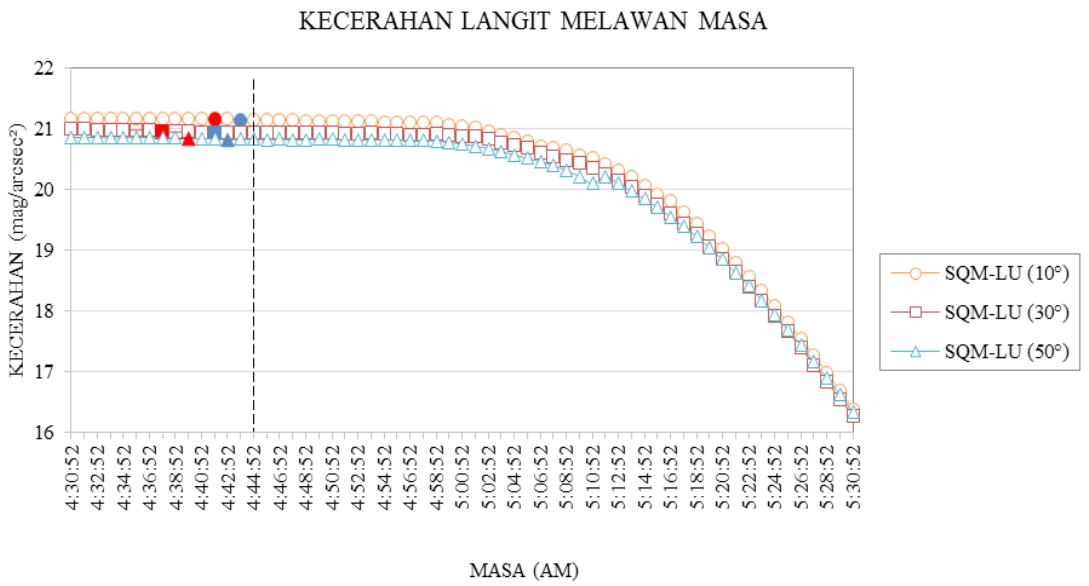




\section{Graf 4: Penentuan Fajar Kazib dan Fajar Șādiq Pada 30/09/2017}

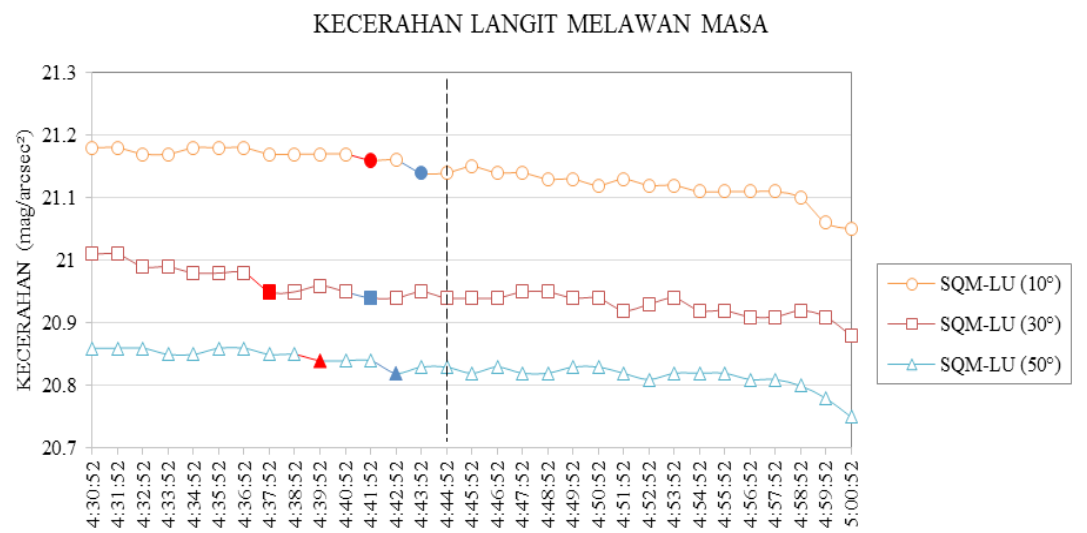

MASA (AM)

\section{Jadual 5: Analisis Data Kecerahan Langit Fajar Pada 30/09/2017}

\begin{tabular}{ccccccc}
\hline \multicolumn{2}{l}{ Waktu Solat (JAKIM) } & \multicolumn{2}{c}{ Fajar Kazib } & \multicolumn{2}{c}{ Fajar Șādiq } \\
\hline $\begin{array}{c}\text { Masa } \\
(\text { AM) }\end{array}$ & $\begin{array}{c}\text { Altitud } \\
\text { Matahari } \\
\left({ }^{\circ}\right)\end{array}$ & $\begin{array}{c}\text { Sudut } \\
\text { Tuju } \\
\text { SQM-LU }\end{array}$ & $\begin{array}{c}\text { Masa } \\
(\text { AM) }\end{array}$ & $\begin{array}{c}\text { Altitud } \\
\text { Matahari } \\
\left({ }^{\circ}\right)\end{array}$ & $\begin{array}{c}\text { Masa } \\
(\text { AM) }\end{array}$ & $\begin{array}{c}\text { Altitud } \\
\text { Matahari } \\
\left({ }^{\circ}\right)\end{array}$ \\
\hline $04: 44: 52$ & -19.661 & $10^{\circ}$ & $04: 41: 52$ & -20.406 & $04: 43: 52$ & -19.909 \\
& & $30^{\circ}$ & $04: 37: 52$ & -21.398 & $04: 41: 52$ & -20.406 \\
& & $50^{\circ}$ & $04: 39: 52$ & -20.902 & $04: 42: 52$ & -20.157 \\
\hline
\end{tabular}

Graf 3 dan 4 di atas menunjukkan fajar șādiq mulai muncul beberapa minit lebih awal sebelum masuknya waktu solat Subuh. Ketika fajar șādiq muncul, altitud matahari ialah -19.909 (SQMLU $\left.10^{\circ}\right),-20.406^{\circ}\left(\mathrm{SQM}-L U 30^{\circ}\right.$ ) dan $-20.157^{\circ}$ (SQM-LU 50 $)$ iaitu masing-masing berbeza sebanyak $\pm 0.091^{\circ}, \pm 0.406^{\circ}$ dan $\pm 0.157^{\circ}$ daripada nilai altitud $20^{\circ}$ yang digunakan di Malaysia untuk menandakan masuknya waktu solat Subuh. Dari sudut cerapan mata kasar dan kamera DSLR, fajar kazib dan fajar șādiq 
tidak dapat dikesan semasa cerapan dilakukan kerana keadaan langit dan ufuk yang berawan.

\section{SET DATA TIGA}

Tarikh

Hari

Waktu solat Subuh

Waktu Syuruq

Keadaan langit

Keadaan ufuk
: 01/10/2017

: Ahad

: 4.44 pagi

: 6.00 pagi

: Cerah dan berawan

: Berawan

\section{Jadual 6: Data Kecerahan Langit Fajar Pada 1/10/2017}

\begin{tabular}{|c|c|c|c|}
\hline \multirow[b]{2}{*}{$\begin{array}{l}\text { Masa } \\
( \pm 1 \text { saat })\end{array}$} & \multicolumn{3}{|c|}{$\begin{array}{c}\text { Kecerahan langit (mag/arkasaat }{ }^{2} \text { ) mengikut sudut } \\
\text { tuju SQM-LU }\end{array}$} \\
\hline & $\begin{array}{l}\text { SQM-LU } \\
\quad\left(10^{\circ}\right)\end{array}$ & $\begin{array}{l}\text { SQM-LU } \\
\quad\left(30^{\circ}\right)\end{array}$ & $\begin{array}{l}\text { SQM-LU } \\
\quad\left(50^{\circ}\right)\end{array}$ \\
\hline $04: 30: 12$ & 21.99 & 21.87 & 21.82 \\
\hline $04: 31: 12$ & 21.99 & 21.87 & 21.82 \\
\hline $04: 32: 12$ & 21.98 & 21.85 & 21.81 \\
\hline $04: 33: 12$ & 21.96 & 21.85 & 21.8 \\
\hline $04: 34: 12$ & 21.96 & 21.85 & 21.81 \\
\hline $04: 35: 12$ & 21.96 & 21.87 & 21.81 \\
\hline $04: 36: 12$ & 21.94 & 21.87 & 21.81 \\
\hline $04: 37: 12$ & 21.93 & 21.86 & 21.8 \\
\hline $04: 38: 12$ & 21.93 & 21.86 & 21.81 \\
\hline $04: 39: 12$ & 21.93 & 21.84 & 21.8 \\
\hline $04: 40: 12$ & 21.91 & 21.84 & 21.78 \\
\hline $04: 41: 12$ & 21.91 & 21.81 & 21.78 \\
\hline $04: 42: 12$ & 21.9 & 21.81 & 21.78 \\
\hline $04: 43: 12$ & 21.9 & 21.8 & 21.77 \\
\hline $04: 44: 12$ & 21.9 & 21.8 & 21.78 \\
\hline $04: 45: 12$ & 21.89 & 21.81 & 21.77 \\
\hline $04: 46: 12$ & 21.89 & 21.8 & 21.78 \\
\hline $04: 47: 12$ & 21.9 & 21.78 & 21.77 \\
\hline $04: 48: 12$ & 21.89 & 21.75 & 21.75 \\
\hline $04: 49: 12$ & 21.85 & 21.73 & 21.75 \\
\hline $04: 50: 12$ & 21.78 & 21.66 & 21.69 \\
\hline $04: 51: 12$ & 21.72 & 21.59 & 21.63 \\
\hline $04: 52: 12$ & 21.66 & 21.53 & 21.59 \\
\hline $04: 53: 12$ & 21.57 & 21.44 & 21.5 \\
\hline
\end{tabular}




\begin{tabular}{lccc}
$04: 54: 12$ & 21.46 & 21.32 & 21.39 \\
$04: 55: 12$ & 21.35 & 21.19 & 21.29 \\
$04: 56: 12$ & 21.22 & 21.05 & 21.18 \\
$04: 57: 12$ & 21.1 & 20.93 & 21.07 \\
$04: 58: 12$ & 20.97 & 20.82 & 20.97 \\
$04: 59: 12$ & 20.84 & 20.71 & 20.85 \\
$05: 00: 12$ & 20.7 & 20.54 & 20.63 \\
$05: 01: 12$ & 20.52 & 20.36 & 20.48 \\
$05: 02: 12$ & 20.32 & 20.14 & 20.28 \\
$05: 03: 12$ & 20.1 & 19.92 & 20.08 \\
$05: 04: 12$ & 19.9 & 19.72 & 19.93 \\
$05: 05: 12$ & 19.68 & 19.5 & 19.73 \\
$05: 05: 12$ & 19.68 & 19.5 & 19.73 \\
$05: 06: 12$ & 19.43 & 19.27 & 19.48 \\
$05: 07: 12$ & 19.18 & 19.02 & 19.22 \\
$05: 08: 12$ & 18.9 & 18.74 & 18.95 \\
$05: 09: 12$ & 18.6 & 18.44 & 18.65 \\
$05: 10: 12$ & 18.31 & 18.12 & 18.36 \\
$05: 11: 12$ & 18.04 & 17.84 & 18.07 \\
$05: 12: 12$ & 17.79 & 17.57 & 17.8 \\
$05: 13: 12$ & 17.56 & 17.32 & 17.53 \\
$05: 14: 12$ & 17.34 & 17.07 & 17.25 \\
$05: 15: 12$ & 17.07 & 16.79 & 16.95 \\
$05: 16: 12$ & 16.79 & 16.48 & 16.63 \\
$05: 17: 12$ & 16.47 & 16.16 & 16.29 \\
$05: 18: 12$ & 16.14 & 15.79 & 15.95 \\
$05: 19: 12$ & 15.8 & 15.42 & 15.59 \\
\hline & & &
\end{tabular}

Graf 5: Data Kecerahan Langit Fajar Pada 1/10/2017

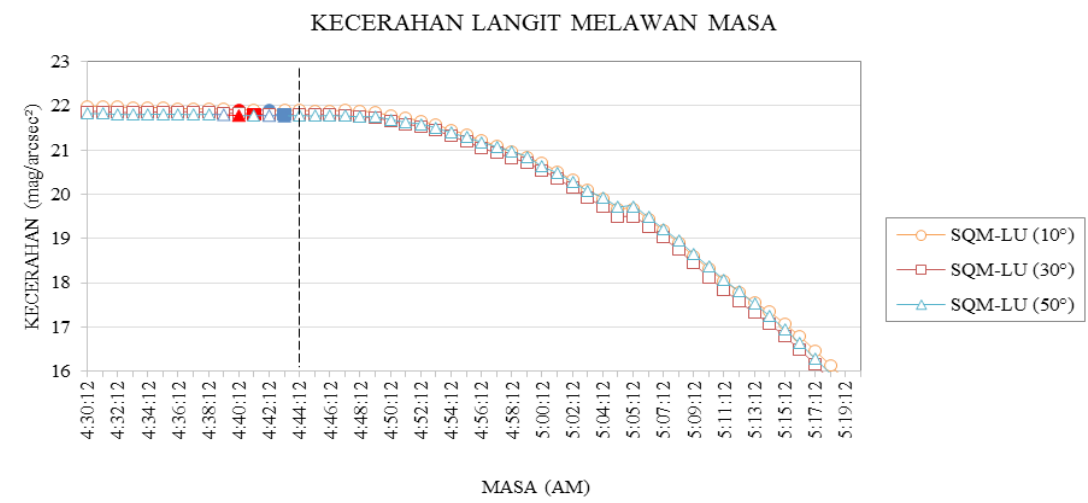




\section{Graf 6: Penentuan Fajar Kazib dan Fajar Șādiq Pada 1/10/2017}

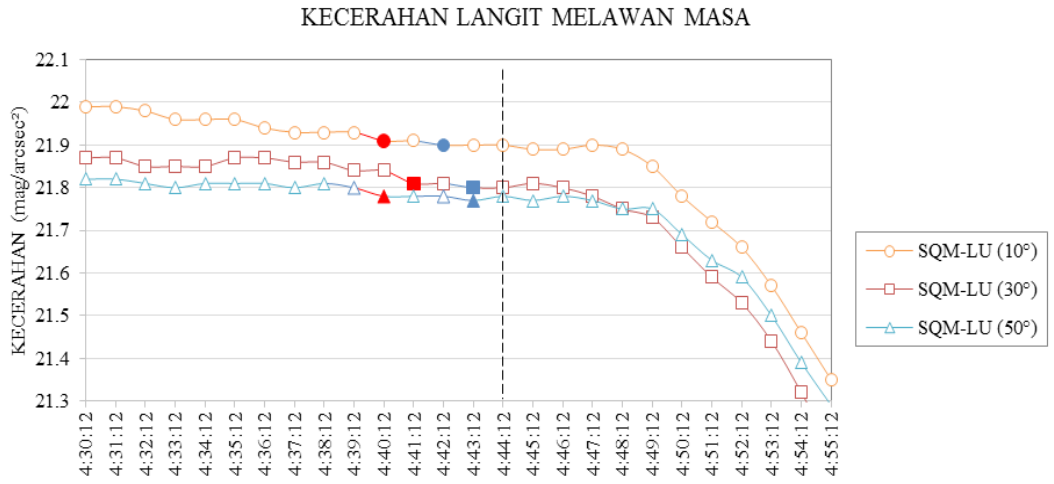

MASA (AM)

\section{Jadual 7: Analisis Data Kecerahan Langit Fajar Pada 1/10/2017}

\begin{tabular}{ccccccc}
\hline \multicolumn{2}{c}{$\begin{array}{c}\text { Waktu Solat } \\
\text { (JAKIM) }\end{array}$} & & \multicolumn{2}{c}{ Fajar Kazib } & \multicolumn{2}{c}{ Fajar Sādiq } \\
\hline $\begin{array}{c}\text { Masa } \\
(\text { AM) }\end{array}$ & $\begin{array}{c}\text { Altitud } \\
\text { Matahari } \\
\left({ }^{\circ}\right)\end{array}$ & $\begin{array}{c}\text { Sudut } \\
\text { Tuju } \\
\text { SQM-LU }\end{array}$ & $\begin{array}{c}\text { Masa } \\
(\text { AM) }\end{array}$ & $\begin{array}{c}\text { Altitud } \\
\text { Matahari } \\
\left({ }^{\circ}\right)\end{array}$ & $\begin{array}{c}\text { Masa } \\
(\text { AM) }\end{array}$ & $\begin{array}{c}\text { Altitud } \\
\text { Matahari } \\
\left({ }^{\circ}\right)\end{array}$ \\
\hline $04: 44: 12$ & -19.788 & $10^{\circ}$ & $04: 40: 12$ & -20.781 & $04: 42: 12$ & -20.284 \\
& & $30^{\circ}$ & $04: 41: 12$ & -20.532 & $04: 43: 12$ & -20.036 \\
& & $50^{\circ}$ & $04: 40: 12$ & -20.781 & $04: 43: 12$ & -20.036 \\
\hline
\end{tabular}

Graf 5 dan 6 di atas turut menunjukkan fajar șādiq mulai muncul beberapa minit lebih awal sebelum masuknya waktu solat Subuh. Ketika fajar șādiq muncul, altitud matahari ialah $-20.284^{\circ}$ (SQM-LU $10^{\circ}$ ) dan $-20.036^{\circ}$ (SQM-LU $30^{\circ}$ dan $50^{\circ}$ ) iaitu masing-masing berbeza sebanyak $\pm 0.0284^{\circ}$ dan $\pm 0.036^{\circ}$ daripada nilai altitud $20^{\circ}$ yang digunakan di Malaysia untuk menandakan masuknya waktu solat Subuh. Dari sudut cerapan mata kasar dan kamera DSLR, fajar kazib dan fajar șädiq tidak dapat dikesan semassa cerapan dilakukan kerana keadaan langit dan ufuk yang berawan. 


\section{Jadual 8: Altitud Matahari Ketika Fajar Kazib dan Fajar} Șädiq

\begin{tabular}{ccc}
\hline Alat Cerapan & Fajar Kazib & Fajar Șādiq \\
\hline & -21.156 & -20.163 \\
SQM-LU $\left(10^{\circ}\right)$ & -20.406 & -19.909 \\
& -20.781 & -20.284 \\
\hline Purata & -20.781 & -20.119 \\
\hline & -20.659 & -20.163 \\
SQM-LU $\left(30^{\circ}\right)$ & -21.398 & -20.406 \\
& -20.532 & -20.036 \\
\hline Purata & -20.863 & -20.202 \\
\hline SQM-LU $\left(50^{\circ}\right)$ & -21.156 & -20.411 \\
& -20.902 & -20.157 \\
\hline Purata & -20.781 & -20.036 \\
\hline Mata Kasar & -20.946 & -20.201 \\
\hline Kamera DSLR & - & - \\
\hline Purata & - & - \\
\hline Keseluruhan & -20.863 & -20.174 \\
Selisihan & \pm 0.323 & \pm 0.170 \\
\hline
\end{tabular}

\section{Graf 7: Altitud Matahari Ketika Fajar Kazib Dan Fajar Șādiq}

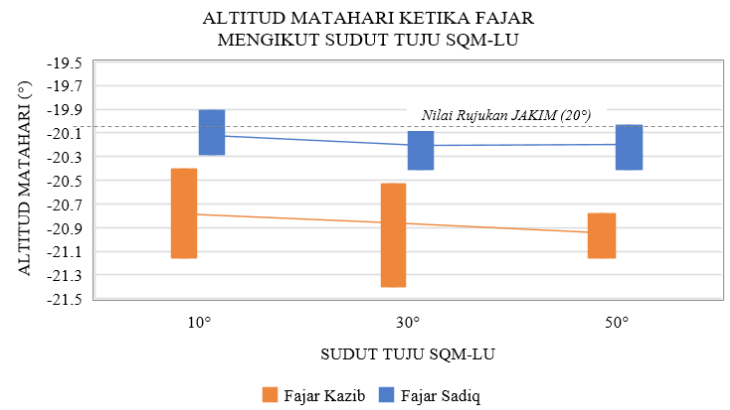


Berpandukan data-data cerapan langit yang diperolehi, jadual 8 dan graf 7 di atas merumuskan julat altitud matahari untuk fajar kazib dan fajar șādiq mengikut sudut tuju SQM-LU yang digunakan dalam pengumpulan data. Secara keseluruhan, purata altitud matahari untuk fenomena fajar kazib yang diperolehi berdasarkan ketiga-tiga keadaan sudut tuju SQM-LU ialah $-20.863^{\circ} \pm 0.323^{\circ}$, manakala bagi fajar șādiq ialah $-20.174^{\circ} \pm$ $0.170^{\circ}$. Perbezaan nilai cerapan fajar șâdiq dengan nilai altitud rujukan $20^{\circ}$ yang digunakan di Malaysia untuk menandakan masuknya waktu solat Subuh ialah $\pm 0.174^{\circ}$ ataupun sebanyak $\pm 0.87 \%$. Nilai yang diperoleh ini masih tidak kukuh kerana ia terhasil hanya daripada analisis graf terhadap data cerapan dan tiadanya data cerapan mata kasar ekoran faktor langit tempatan dan keadaan ufuk yang berawan. Kaedah analisis graf ini sendiri sekiranya terdapat kekurangan perlu dibaiki. Nilai yang kukuh dan komprehensif dapat dipertimbangkan terbentuk daripada integrasi pelbagai kaedah, terutamanya cerapan mata kasar (naked-eye), cerapan dengan alat bantu (aided-eye) dan kiraan matematik serta teruji secara teori dan di lapangan.

Merujuk data-data cerapan yang diperoleh, pengkaji berpandangan bahawa penggunaan nilai altitud matahari $20^{\circ}$ untuk mensabitkan tanda masuknya waktu solat Subuh dalam penyediaan taqwim waktu solat adalah masih munasabah untuk lokasi terbabit. Sekiranya nilai altitud $20^{\circ}$ adalah sememangnya nilai rujukan terbaik untuk menunjukkan cahaya pertama terbitnya fajar șâdiq dalam keadaan cuaca langit cerah, maka sebarang perbezaan nilai cerapan dan nilai rujukan itu berkemungkinan tinggi adalah disebabkan nilai cerapan dipengaruhi oleh faktor keadaan langit tempatan yang berawan seperti berlaku di lokasi cerapan (lihat rajah 6). 


\section{Rajah 6: Keadaan Langit Tempatan Berawan di Pantai Bak- bak, Kudat, Sabah Pada 30/09/2017}

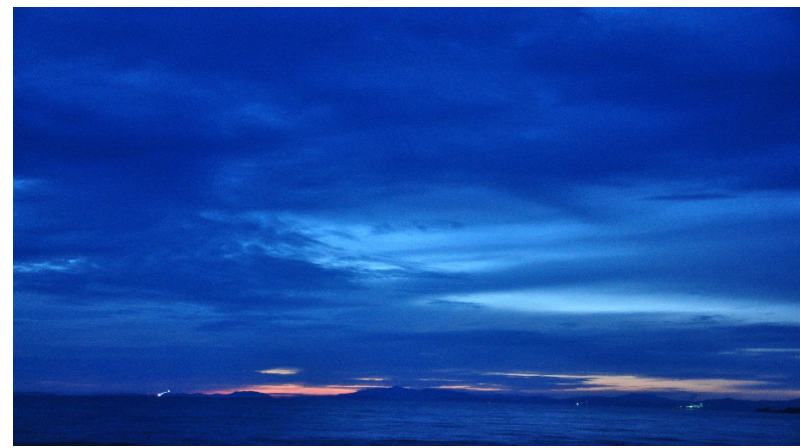

Ini kerana secara asas, sebagaimana dinyatakan oleh Yallop (1996), tiada persetujuan untuk memberi takrifan secara tepat terhadap maksud fajar (dawn). Menurut Yallop (1996), kalaupun sekiranya ia ingin ditakrifkan sebagai cahaya pertama yang muncul semasa matahari terbit, maka fenomena fajar terbabit berlaku ketika nilai altitud matahari di antara $-18^{\circ}$ hingga $-12^{\circ}$ tetapi tidak mustahil nilainya boleh jadi lebih tepat. Penting diketahui bahawa kecerahan langit fajar begitu dipengaruhi oleh keadaan meteorologi tempatan seperti kelembapan dan awan, serta topografi tempatan seperti kehadiran pokok-pokok dan bangunan. Demikian juga, keadaan astronomi seperti cahaya bulan di mana sekiranya bulan penuh berada di ufuk timur, kecerahan fajar boleh bertambah dan jangka masanya boleh berlaku lebih panjang. Bagaimanapun untuk kawasan latitud rendah seperti khatulistiwa, jangka masa berlakunya fenomena fajar adalah lebih pendek di antara 1 jam 8 minit dan 1 jam 16 minit. ${ }^{38}$

Walau apapun, pengkaji berpandangan bahawa apa-apa nilai altitud matahari yang dimuktamadkan untuk menetapkan awal waktu solat Subuh dan sekali gus sebagai tanda kepada terbitnya fajar șādiq, adalah lebih kukuh sekiranya nilai terbabit terhasil daripada integrasi pelbagai kaedah penentuan dari cerapan

38 Yallop, B. D. \& C. Y. Hohenkerk, A Note on Sunrise, Sunset and Twilight Times and on the Illumination Conditions During Twilight: Astronomical Information Sheet (Cambridge: HM Nautical Almanac Office. No. 7, 1996), http://astro.ukho.gov.uk/nao/aisinfo/ais007.pdf dicapai pada 24 April 2019. 
mata kasar (naked-eye), cerapan dengan alat bantu (aided-eye) sehinggalah kiraan matematik antaranya secara statistik untuk melihat lebih terperinci kebarangkalian nilainya adalah konsisten di pelbagai tempat yang berbeza serta bagi mencapai nilai terbaik yang komprehensif.

\section{KESIMPULAN}

Berdasarkan cerapan, nilai altitud matahari untuk menunjukkan terbitnya fajar șādiq dan menandakan masuknya waktu solat Subuh ialah $-20.174^{\circ} \pm 0.170^{\circ}$ dengan perbezaan $\pm 0.174^{\circ}$ ataupun sebanyak $\pm 0.87 \%$ daripada nilai altitud $-20^{\circ}$ yang digunakan di Malaysia. Nilai yang diperolehi ini masih kurang kukuh kerana ia terhasil hanya daripada analisis graf terhadap data cerapan dan tiadanya data cerapan mata kasar ekoran faktor langit tempatan dan keadaan ufuk yang berawan. Nilai terbaik yang kukuh dan komprehensif dapat dipertimbangkan terbentuk daripada integrasi pelbagai kaedah, terutamanya cerapan mata kasar (nakedeye), cerapan dengan alat bantu (aided-eye) dan kiraan matematik serta teruji secara teori dan di lapangan. Secara pasti, kepelbagaian dapatan nilai altitud matahari bagi menandakan fajar șādiq daripada lapangan kajian kuantitatif dan kepelbagaian tafsiran para fuqaha dan penyelidik terhadap fenomenanya daripada lapangan kajian kualitatif hanya membuktikan bahawa fenomena fajar șädiq sebagai tanda awal waktu solat Subuh adalah bersifat dinamik. Kedinamikan inilah yang mendorong budaya berfikir dan semangat mengkaji dalam kalangan umat Islam. Dengan itu, adalah menjadi tanggungjawab para pengkaji dan pencinta ilmu untuk berusaha menyediakan suatu pendekatan terbaik yang dapat mentarjih paradigma, kaedah dan hasil kajian terdahulu. Pendekatan sedemikian penting dibangunkan secara bersepadu iaitu bukan sahaja dapat memenuhi tuntutan syarak dan kukuh nilai saintifiknya, malah ia dapat merumus secara muktamad kedinamikan fenomena fajar șādiq yang menandakan masuknya waktu solat Subuh, berakhirnya waktu Isyak dan bermulanya ibadah puasa. 


\section{PENGHARGAAN}

Penyelidikan ini adalah sebahagian daripada geran Bantuan Kecil Penyelidikan (BK065-2017). Pengkaji merakamkan penghargaan dan terima kasih kepada Universiti Malaya atas bantuan kewangan melalui geran ini. Penghargaan dan terima kasih juga pada pelbagai pihak yang membantu secara langsung atau tidak langsung kepada penyelidikan ini, terutamanya pihak Jabatan Kemajuan Islam Malaysia (JAKIM) yang telah mengundang pengkaji membentangkan hasil awal kajian ini dalam Muzakarah Falak 2017, kemudian pihak Institut Tanah dan Ukur Negara (INSTUN) dan Jabatan Mufti Negeri Perak yang menyediakan platform untuk pengkaji membentangkan hasil akhir kajian ini iaitu rumusan perspektif integrasi ilmu Syariah dan astronomi dalam Seminar Falak Nusantara 2018.

\section{RUJUKAN}

'Abd Allāh al-Misnid. "Mushkilah Tạ̣dīd Waqt al-'Ishā' wa al-Fajr fì al-Manāțiq al-Jugrafiyyah al-Mutațarrifah Makāniyyan wa Mawāqit al-Ṣalāh li Ruwad al-Fadā' alMuslimīn." http://www.icoproject.org/pdf/almisnid_2010. pdf., dicapai pada 24 April 2019.

"Abd Allāh al-Misnid. "Taḥdīd Waqt Dukhūl Șalāh al-Fajr "Amaliyyan bi Manțaqah al-Qāșim." http://www.icoproject. org/pdf/almisnid_2012.pdf., dicapai pada 24 April 2019.

'Abd al-Qādir 'Abid. "Tahdid Maw'id Hulul al-Fajr al-Ṣādiq fī al-Urdūn bi al-Rasd al-Falāk al-Mubāshir bi al-'Ayn alMujarradah," al-Majallah al-Urdūniyyah fì al-Dirāsah alIslämiyyah, vol. 11, no. 2 (2015).

Abū al-Fadl Jamāl al-Dīn Muḥammad Ibn Mukarram al-Anșārī Ibn Manẓūr. Lisān al- 'Arab, vol. 5. Bayrūt: Dār Șadr, 1994.

Aḥmad Ibn Hanbal. Musnad Imām Ahmad Ibn Hanbal, vol. 12. Qāhirah: Dār al-Hadīth,1995.

Baharrudin Zainal. Pengenalan Ilmu Falak. Kuala Lumpur: Dewan Bahasa dan Pustaka, 2002.

Gardner, Fiona. "Critical Reflection in Community-Based Evaluation," Qualitative Social Work, vol. 2, no. 2 (2003), 197-212. 
Hardi Mohamad Sadali, Jasni Sulong \& Abdul Halim Abdul Aziz. "Parameter Kedudukan Matahari Bawah Ufuk Bagi Penentuan Waktu Solat Subuh dan Isyak e-Falak," http:// apps.islam.gov.my/efalak/?q=en/artikel-kertas-kerja, dicapai pada 3 April 2014.

Hassan, A.H. et al. "Naked Eye Observations for Morning Twilight at Different Sites in Egypt," NRIAG: Journal of Astronomy and Geophysics, vol. 3, no. 1 (2014), 23-26.

Herdiwijaya, D. "Implications of Twilight Sky Brightness Measurements on Fajr Prayer and Young Crescent Observation." Proceeding 7th International Conference on Physics and Its Applications, Solo, Indonesia, 16-17 September 2014.

Ibrāhīm Muhammad al-Șabīhī. Tulū' al-Fajr al-Sadīq bayna Tahdīd al-Qur'ān wa Iṭlāq al-Lughah. Riyāḍ: Maktabah alMālik Fahd, 2007.

Jabatan Mufti Negeri Selangor. Kaedah Penentuan dan Pengiraan Waktu Solat. Shah Alam: Jabatan Mufti Negeri Selangor, 2005.

Laman web e-Fatwa. http://www.e-fatwa.gov.my/fatwa-negeri/ tafsiran-fajar-sadiq-dalam-penentuan-waktu-Subuhmenurut-syarak.

Laman web e-Solat. http://www.e-solat.gov.my/web/index1. php?id $=55 \&$ type $=$ A.

Liebert, Wolfgang \& Jan C. Schmidt. "Towards A Prospective Technology Assessment: Challenges and Requirements for Technology Assessment in the Age of Technoscience," Poiesis \& Praxis, vol. 7, no. 1-2 (2010), 99-116.

Moh Amrullah. "Penentuan Awal Waktu Shalat Subuh Menurut Departemen Agama dan Aliran Salafi: Sebuah Kajian Falakiyah," Jurnal Hukum dan Syariah, vol. 2, no. 2 (2011), 120-134.

Mohd Saleh Mohd@Ahmad. "Penentuan Waktu Solat Menurut Fiqh.” Kertas kerja, Konvensyen Falak Selangor 2007, Kolej Islam Sultan Alam Shah, Klang, Selangor, 20-21 Julai 2007. 
Muhammad Shamim Shukor \& Mohd Zambri Zainuddin. "Perbandingan Metodologi Kajian Penentuan Masuknya Fajar Sadiq dan Hilangnya Syafaq Ahmar: Kajian Kecerahan Langit," Jurnal Falak, no. 1 (2015), 133-139.

Muhammad Shamim Shukor et al. "Kajian Kecerahan Langit di Malaysia," dalam Dimensi Penyelidikan Astronomi Islam, ed. Saadan Man et al. Kuala Lumpur: Jabatan Fiqh dan Usul, Akademi Pengajian Islam, Universiti Malaya, 2013.

Muḥammad Shawkah Odeh. "Ishkāliyyat Falākiyyah wa Fiqhiyyah Ḥawla Tạ̣dīd Mawāqīit al-Șalāt." http://www. icoproject.org/pdf/Salat_Problems_2010.pdf., dicapai pada 24 April 2018.

Nazhatulshima Ahmad et al. "Kajian Kecerahan Langit di Ufuk Senja dan Fajar," Jurnal INSTUN, vol. 1, no. 2 (2007), h. 51.

Norihan Kadir. "Penilaian Semula Parameter Penentuan Awal Waktu Solat Subuh di Malaysia dari Perspektif Astronomi Islam,” Disertasi Sarjana, Jabatan Fiqh dan Usul, Akademi Pengajian Islam, Universiti Malaya, 2017.

Nugroho Eko Atmanto. "Relevansi Konsep Fajar dan Senja dalam Kitab al-Qanun al-Mas'udi bagi Penetapan Waktu Salat Isya' dan Subuh," Jurnal Analisa, vol. 19, no. 1 (2012), 95105.

Nur Nafhatun et al. "Background Theory of Twilight in Isha' and Subh Prayer Times," dalam Dimensi Penyelidikan Astronomi Islam, ed. Saadan Man et al. Kuala Lumpur: Jabatan Fiqh dan Usul, Akademi Pengajian Islam, Universiti Malaya, 2013.

Nur Nafhatun Mohd Shariff. "Sky Brightness at Twilight: Detectors Comparisan between Human Eye and Electronic Devise for Isha \& Subh from Islamic and Astronomical Considerations," Disertasi Sarjana, Jabatan Pengajian Sains dan Teknologi, Fakulti Sains, Universiti Malaya, Kuala Lumpur, 2010. 
Nurul Asikin Che Daud et al. "Towards the unification of twilight parameters for determination of Fajr and Isha in Malaysia." https://www.mygeoportal.gov.my/ms/towards-unificationtwilight-parameter-determination-fajr-and-isha-malaysia. Dicapai pada 25 April 2019.

Nurul Huda Ahmad Zaki et al. "Modern and Traditional Calculation Method in the Determination of Prayer Times in Malaysia: Analysis of Accuracy Comparison," Journal of Research in Islamic Studies, vol. 1, no. 2 (2014), h. 31-34.

Nurul Huda Ahmad Zaki et al. "Penentuan Waktu Solat Subuh Menggunakan Rubu'Mujayyab di Malaysia," Jurnal Fiqh, vol. 11 (2014), 97-118.

Raihana,A.W, Norihan, K., Mutafa, M.H. "Issues on Determination of-Accurate Fajr and Dhuha Prayer Times According to Fiqh and Astronomical Perspectives in Malaysia: A Bibliography Study," Conference Proceedings Bali, Indonesia, 13-14 October 2016.

Rohmah, N. "The Effect of Atmospheric Humidity Level to the Determination of Islamic Fajr/Morning Prayer Time and Twilight Appearance," Journal of Physics: Conference Series, vol. 771, no. 1 (2016), 12-48.

Sahịh Muslim. no. hadith 220, jilid-5, diakses daripada laman sesawang Sunnah.com https://sunnah.com/muslim/5.

Siti Asma' Mohd Nor \& Zainuddin, M. Z. "Sky Brightness for Determination of Fajr and Isha Prayer by Using Sky Quality Meter," International Journal of Scientific \& Engineering Research, vol. 3, no. 8 (2012), h. 1-3.

Susiknan Azhari. "Awal Waktu Salat Subuh di Dunia Islam," Kertas Kerja, Persidangan Penyatuan Awal Waktu Salat Subuh, Fakultas Syari'ah dan Hukum UIN Alauddin, Makassar, 2013.

Thomas Djamaludin. "Waktu Solat Subuh Ditinjau dari Dalil Syar'i dan Astronomi," https://tdjamaluddin.wordpress. com/2010/04/15/waktu-shubuh-ditinjau-secara-astronomidan-syari/, dicapai pada 24 April 2019.

Wahbah al-Zuhaylī. al-Fiqh al-Islāmī wa Adillatuh. Dimashq: Dār al-Fikr, 2004. 
Yallop, B. D. \& C. Y. Hohenkerk, A Note on Sunrise, Sunset and Twilight Times and on the Illumination Conditions During Twilight: Astronomical Information Sheet. Cambridge: HM Nautical Almanac Office. No. 7, 1996.

Yetim, Fahri. "Supporting and Understanding Reflection on Persuasive Technology Through A Reflection Schema," Paper presented, International Conference on Persuasive Technology, Springer, Cham, 2019, 43-51. 
Jurnal Fiqh, Vol. 16 No. 2 (2019) 253-288 